\title{
EFFECTS OF ESSENTIAL OIL COMBINATIONS ON PATHOGENIC YEASTS AND MOULDS
}

\author{
Györgyi Horváth, ${ }^{1}$ * Julianna TÖröK Jenei, ${ }^{2}$ CsABA VÁGVÖlgyi, ${ }^{3}$ \\ ANDREA BÖSZÖRMÉNYI ${ }^{4}$ and JUDIT KRISCH ${ }^{2}$ \\ IInstitute of Pharmacognosy, Faculty of Pharmacy, University of Pécs, \\ Rókus u. 2, H-7624 Pécs, Hungary \\ ${ }^{2}$ Institute of Food Engineering, Faculty of Engineering, University of Szeged, \\ Mars tér 7, H-6724 Szeged, Hungary \\ ${ }^{3}$ Department of Microbiology, Faculty of Science and Informatics, University of Szeged, \\ Közép fasor 52, H-6726 Szeged, Hungary \\ 4Institute of Pharmacognosy, Faculty of Pharmacy, Semmelweis University, \\ Üllői út 26, H-1085 Budapest, Hungary
}

(Received: August 11, 2015; accepted: November 11, 2015)

\begin{abstract}
Essential oils (EOs) can be used as alternative or complementary antifungal agents against human pathogenic moulds and yeasts. To reduce the effective dose of antimicrobial agents, EOs are combined which can lead to synergistic or additive effect. In this study the anti-yeast and anti-mould activities of selected EOs were investigated, alone and in combinations, against clinical isolates of Candida albicans, C. parapsilosis, Aspergillus fumigatus, A. terreus, Rhizopus microsporus, Fusarium solani and Lichtheimia corymbifera. Minimum inhibitory concentrations (MICs) were determined for the EOs of cinnamon, citronella, clove, spearmint and thyme. To investigate the combination effect of the EOs, fractional inhibitory concentrations (FICs) were defined by the checkerboard method and the type of interaction was determined by the FIC index (FICI). FIC index below 0.5 was considered as synergism and between 0.5 and 1 as additive effect. Strongest antifungal activity was showed by thyme EO with MIC values below $1.0 \mathrm{mg} / \mathrm{ml}$. Combination of EOs resulted in additive or indifferent effect, with occasional "borderline synergism". The best combination was cinnamon with clove leading to additive effect in all cases.
\end{abstract}

Keywords: Essential oils - fungal pathogens - fractional inhibitory concentration - combined effect

\section{INTRODUCTION}

Fungal infections are severe diseases among immunocompromised and immunosuppressed patients, causing sometimes life-threatening conditions. Both yeasts and moulds are involved as causative agents and the symptoms range from topical to systemic. Among yeasts, Candida species were the most frequently isolated organisms. The main cause of the infection, called candidiasis, is Candida albicans but other Candida species are also involved [7]. Candidiasis can affect the mouth, the vagina, and rarely a serious invasive form can develop.

Inhalation of mould spores can lead to allergic symptoms but sometimes moulds can grow in the human body causing severe damage to the lung, eye and skin. Invasive aspergillosis is the most common filamentous fungal infection diagnosed in

*Corresponding author; e-mail address: gyorgyi.horvath@aok.pte.hu 
immunocompromised patients [29]. Species involved in this disease are Aspergillus fumigatus, A. flavus, A. niger and A. terreus [3, 20,29]. Zygomycosis used to be very rare but has become an emerging infection because the growing numbers of risk factors like diabetes, neutropenia, bone marrow transplantation, long-term use of steroids, and chemotherapy in patients with haematological malignancy [2, 8, 31]. Species described as causative agents are Rhizopus microsporus and Lichtheimia (formerly Absidia) spp. The plant pathogen fungus Fusarium solani was reported causing mycotic keratitis in neutropenic patients [33]. Treatment of mycoses is not easy; it requires long time and agents may cause toxic side-effects on the human body. Resistance against antifungals is quite common among fungal pathogens; most A. terreus strains, e.g., are resistant to amphotericin B [3,29], and the number of fluconazole-resistant Candida species is also increasing [1,26]. The search for natural antifungal agents has gained interest recently because these could provide alternative solutions with less or no toxic side-effects and their combined use with standard therapeutic agents could enhance the effectiveness of treatment. Essential oils (EOs) are well-known antimicrobials and their use as preservatives, disinfectants or therapeutic agents has been under intensive research [6]. Combination of EOs could lead to synergism, decreasing the effective concentration. The aim of this study was to investigate the combined effect of selected EOs (cinnamon, citronella, clove, spearmint and thyme) on human pathogenic yeasts and moulds.

\section{MATERIALS AND METHODS}

\section{Strains and culture conditions}

The fungal strains used in this study were from the Szeged Microbiological Collection (SZMC, WDCM 987) and were isolated from human infections: C. albicans SZMC 1363 (vaginal mycosis); C. parapsilosis SZMC 1408 (CBS 604 - intestinal mycosis); Aspergillus fumigatus SZMC 2394 (keratomycosis); A. terreus SZMC 2394 (keratomycosis); Fusarium solani SZMC 11412 (keratomycosis), Rhizopus microsporus SZMC 13644 (CBS220.92 - human mycosis) and Lichtheimia corymbifera FSU 9682 (unknown origin). The yeasts and moulds were cultured on malt extract medium $\left(0.4 \%\right.$ malt extract, $1 \%$ glucose, $0.1 \%$ yeast extract) at $30^{\circ} \mathrm{C}$.

\section{Essential oils}

The EOs of cinnamon bark (Cinnamomum zeylanicum Presl.), clove (Syzygium aromaticum (L.) Merill et Perry), thyme (Thymus vulgaris L.), citronella (Cymbopogon nardus (L.) Rendle), and spearmint (Mentha spicata $\mathrm{L}$.) were purchased from Aromax Zrt. (Budapest, Hungary). The quality of EOs used in this study met the standards described in the European Pharmacopoeia $4^{\text {th }}$ edition. The EOs used in this study in 
combination were chosen from 15 essential oils based on the results of previous studies [13].

\section{Gas Chromatography}

The percentage evaluation of the essential oil samples was made using a Fisons GC 8000 gas chromatograph (Carlo Erba, Milan, Italy), equipped with a flame ionization detector (FID). An Rt- $\beta$-DEXm (Restek) capillary column, $30 \mathrm{~m} \times 0.25 \mathrm{~mm}$ i.d., 0.25 $\mu \mathrm{m}$ film thickness, was used. The carrier gas was nitrogen at $6.8 \mathrm{ml} / \mathrm{min}$ flow rate; $0.2 \mathrm{ml}$ of a $0.1 \%$ solution was injected $(1 \mathrm{ml}$ essential oil in $1 \mathrm{ml}$ chloroform). Splitless injection was carried out. The temperatures of the injector and detector were $210{ }^{\circ} \mathrm{C}$ and $240{ }^{\circ} \mathrm{C}$, respectively. The oven temperature was increased at a rate of $8{ }^{\circ} \mathrm{C} / \mathrm{min}$ from $60^{\circ} \mathrm{C}$ to $230^{\circ} \mathrm{C}$, with a final isotherm at $230^{\circ} \mathrm{C}$ for $5 \mathrm{~min}$. Identification of peaks was made by retention time and standard addition; percentage evaluation was carried out by area normalization. We made three parallel measurements, RSD was below $4.5 \%$.

\section{$G C-M S$ conditions}

The essential oil compounds were identified with an Agilent 6890N/5973N GC-MSD (Santa Clara, CA, USA) system equipped with an Agilent HP-5MS capillary column $(30 \mathrm{~m} \times 250 \mu \mathrm{m} \times 0.25 \mu \mathrm{m})$. The GC oven temperature was programmed to increase from $60{ }^{\circ} \mathrm{C}\left(3 \mathrm{~min}\right.$ isothermal) to $200{ }^{\circ} \mathrm{C}$ at $8{ }^{\circ} \mathrm{C} / \mathrm{min}$ ( $2 \mathrm{~min}$ isothermal), from 200 $230{ }^{\circ} \mathrm{C}$ at $10{ }^{\circ} \mathrm{C} / \mathrm{min}\left(5 \mathrm{~min}\right.$ isothermal) and finally from $230-250{ }^{\circ} \mathrm{C}$ at $10{ }^{\circ} \mathrm{C} / \mathrm{min}$ (1 $\mathrm{min}$ isothermal). High purity helium was used as carrier gas at $1.0 \mathrm{ml} / \mathrm{min}$ $(37 \mathrm{~cm} / \mathrm{s})$ in constant flow mode. The injections were made directly from the diluted essential oil, $1 \mathrm{ml}(10 \mathrm{ml} / \mathrm{ml}$ essential oil in hexane) was injected at $0.7 \mathrm{mg} / \mathrm{ml}$ velocity, splitless type, with an Agilent 7683 autosampler. The injector temperature was $250^{\circ} \mathrm{C}$ and the split ratio was 1:50. The mass selective detector was equipped with a quadrupole mass analyser and was operated in electron ionization mode at $70 \mathrm{eV}$ in full scan mode (41-500 amu at $3.2 \mathrm{scan} / \mathrm{s})$. The data were evaluated using MSD ChemStation D.02.00.275 software (Agilent). The identification of the compounds was carried out by comparing retention times and recorded spectra with the data of authentic standards, and the NIST 05 library was also consulted.

\section{Determination of MIC (MFC) values}

MIC values were determined by macrodilution for yeasts and by poisoned food method for moulds [24, 17]. Briefly: Into test tubes containing $1 \mathrm{ml}$ malt extract medium $1 \mathrm{ml} \mathrm{EO}$ solutions were added in a concentration range of $0.4-50 \mathrm{mg} / \mathrm{ml}$ in twofold increments. EO solution were made from a stock solution $(100 \mathrm{mg} / \mathrm{ml}$ in 50 
$\mathrm{v} / \mathrm{v} \%$ ethanol) with malt extract medium containing $1 \%$ Tween 40 for the solubilisation of the EOs. Final concentration of EOs in the tubes ranged from 0.2 to $25 \mathrm{mg} /$ $\mathrm{ml}$. The tubes were inoculated with $0.1 \mathrm{ml} 24 \mathrm{~h}$ old yeast suspension $\left(10^{5} \mathrm{cfu} / \mathrm{ml}\right)$. After incubation for $24 \mathrm{~h}$ growth was checked by the track dilution method [14]. $10 \mu \mathrm{l}$ samples were dropped on plates containing malt extract medium and allowed to migrate through the plate. After drying the plates were incubated for 24 hours at $30{ }^{\circ} \mathrm{C}$ and number of colonies was evaluated. MIC was considered as the EO concentration where no colonies were detected. For moulds the essential oils were mixed in a concentration range of 0.2 to $25 \mathrm{mg} / \mathrm{ml}$ to $10 \mathrm{ml}$ medium and poured into Petri dishes. After solidification of the medium spore suspension $\left(10^{5} \mathrm{cfu} / \mathrm{ml}\right)$ obtained from $72 \mathrm{~h}$ old mould cultures were spread on the plates and the plates were incubated for 1 week. MIC was considered as the lowest EO concentration where no growth was detected.

Experiments were repeated three times.

\section{Combination of essential oils}

Checkerboard method was used to investigate the effect of EO combinations. For yeasts test tubes were arranged in a $4 \times 4$ pattern and filled with $1 \mathrm{ml}$ malt extract medium. $1 \mathrm{ml} \mathrm{EO}$ solutions were mixed to the medium in the following matter: the first member of an EO pair was added to the tubes in rows in 0; MIC/2; MIC and 2 MIC concentrations giving a final concentration of 0 ; MIC/4; MIC/2 and MIC. MIC for each $\mathrm{EO}$ was determined in the previous experiment. The other member of the EO pair was added to tubes in the columns also in 0 ; MIC/2; MIC and 2 MIC concentration. In this way all possible combinations can be checked. The first tube containing no EO $(0+0 \mathrm{mg} / \mathrm{ml}$ for the EO pair) was considered as the positive control. The tubes were inoculated with $0.1 \mathrm{ml} 24 \mathrm{~h}$ old yeast suspension $\left(10^{5} \mathrm{cfu} / \mathrm{ml}\right)$ then incubated for $24 \mathrm{~h}$ at $30^{\circ} \mathrm{C}$. After incubation $10 \mu \mathrm{l}$ from each tube was used to check growth by the track dilution method. For moulds EOs were mixed to agar containing medium in the same way, poured into Petri dishes and inoculated with spore suspensions $\left(10^{5} \mathrm{cfu} /\right.$ $\mathrm{ml})$. After incubation for 1 week growth was checked and the first combination where no growth occurred was used to determine the fractional inhibitory index (FICI). Fractional inhibitory concentration (FIC) was determined from MIC values determined for an $\mathrm{EO}$ alone or in combination: $\mathrm{FIC}=$ [MIC in combination]/[MIC alone]. $\mathrm{FICI}=\mathrm{FIC}_{\mathrm{A}}+\mathrm{FIC}_{\mathrm{B}}$ where $\mathrm{FIC}_{\mathrm{A}}$ and $\mathrm{FIC}_{\mathrm{B}}$ are the fractional inhibitory concentrations for the two EOs of an EO pair. Results are interpreted as synergy $(\mathrm{FICI}<0.5)$, addition $(0.5 \geq \mathrm{FICI} \leq 1)$, indifference $(1>\mathrm{FICI} \leq 4)$ or antagonism $(\mathrm{FICI}>4)[17]$.

Pairs of EOs were chosen based on their main components and low MIC values. EOs containing phenolic compounds (cinnamon, thyme and clove) were combined with each other or with citronella or spearmint containing mainly monoterpenes.

All experiments were repeated three times. 


\section{RESULTS}

\section{Composition of essential oils}

The chemical composition of the EOs of cinnamon bark, clove, thyme, citronella and spearmint can be seen in Table 1. Cinnamaldehyde (74.0\%) containing an aromatic ring was the main compound in cinnamon bark oil. Other important constituents identified in this EO were cinnamyl acetate (5.3\%), linalool $(3.8 \%)$ and eugenol $(2.7 \%)$. In the clove oil eugenol $(88.6 \%)$ was the main constituent, and the other relevant compound was identified as $\beta$-caryophyllene $(8.6 \%)$. The phenolics thymol $(46.3 \%)$ and p-cymene $(22.1 \%)$ were the main compounds in thyme essential oil. Carvacrol was present in $3.2 \%$ in this oil. Citronella oil contained the oxygenated terpenes citronellal (36.2\%), geraniol $(25.3 \%)$, and citronellol $(13.6 \%)$ and the nonoxygenated terpene limonene $(3.5 \%)$ as the most relevant compounds. In the spearmint oil (-)-R-carvone (69.0\%) another oxygenated terpene was the main compound, but limonene was also present in remarkable quantity $(21.2 \%)$.

\section{MIC/MFC values}

MIC values for Candida species and moulds are presented in Table 2. The most sensitive strains seemed to be C. albicans and C. parapsilosis with MICs below $1.0 \mathrm{mg}$ / $\mathrm{ml}$ for almost all EOs. In general, spearmint showed weak antifungal activity; in most cases MIC was not detected because in previous screening experiments with paper discs containing $100 \mathrm{mg} / \mathrm{ml} \mathrm{EO}$ no inhibition zone was detected [13]. Best results were achieved with thyme EO showing MIC values below $1 \mathrm{mg} / \mathrm{ml}$ for all of the investigated fungi. In another study thyme EO also showed a broad fungitoxic spectrum on different aspergilli and F. oxysporum [17]. Cinnamon, citronella, and clove showed good antifungal activity against most of the investigated species. Rhizopus species are known to be insensitive to most of the common antifungals because of their numerous hydrolyzing enzymes can break down the active molecules [32]. In the study of Tzortzakis and Costas [32] lemongrass oil showed moderate inhibition on the colony growth of $R$. stolonifer but spore formation was totally inhibited at 500 ppm concentration. In our study, only the EOs of clove, spearmint and thyme showed inhibition activity against $R$. microsporus. The investigated aspergilli and $F$. solani were all sensitive to cinnamon, clove and thyme EOs and showed partial sensitivity to citronella. Pawar et al. [23] also found that cinnamon bark or leaf EO inhibited the growth of $A$. niger.

\section{Combination of essential oils}

Results of the combination of EOs are presented in Table 3. Most of the interactions were additive or indifferent. In the former case, FICI values were $0.5-0.75$ and the 
Table 1

The percentage composition of the investigated essential oils

\begin{tabular}{|c|c|c|c|c|c|c|c|}
\hline \multirow{2}{*}{$\begin{array}{c}\mathrm{t}_{\mathrm{R}} \mathrm{MS} \\
(\mathrm{min})\end{array}$} & \multirow{2}{*}{$\begin{array}{l}t_{R} \text { FID } \\
(\min )\end{array}$} & \multirow{2}{*}{ Compound } & Cinnamon & Citronella & Clove & Spearmint & Thyme \\
\hline & & & \multicolumn{5}{|c|}{$\%$} \\
\hline 5.9 & 5.8 & $\alpha$-Pinene & 0.5 & - & - & 0.5 & 0.9 \\
\hline 6.3 & 6.2 & Camphene & - & - & - & - & 0.9 \\
\hline 6.9 & 6.7 & $\beta$-Pinene & - & - & - & 0.6 & 1.4 \\
\hline 7.7 & 7.2 & $\alpha$-Terpinene & - & - & - & - & 2.2 \\
\hline 8.0 & $7.4-7.5$ & Limonene & 1.4 & 3.5 & - & 21.2 & - \\
\hline 7.9 & 7.6 & $p$-Cymene & 1.2 & - & - & - & 22.1 \\
\hline $8.0-8.1$ & $7.9-8.0$ & 1,8-Cineole & 2.1 & - & - & - & 9.8 \\
\hline 8.6 & 8.5 & $\gamma$-Terpinene & - & - & - & - & 0.3 \\
\hline \multirow[t]{2}{*}{9.5} & 10.1 & Linalool & 3.8 & - & - & - & 5.1 \\
\hline & 10.2 & Neral & - & 1.0 & - & - & - \\
\hline 10.5 & 11.0 & Citronellal & - & 36.2 & - & - & - \\
\hline 10.7 & 11.2 & Geranial & - & 2.2 & - & - & - \\
\hline 10.6 & 11.3 & Menthone & - & - & - & 1.1 & - \\
\hline 11.5 & 11.7 & Terpinen-4-ol & - & - & - & - & 0.6 \\
\hline 11.0 & 12.4 & Borneol & - & - & - & - & 1.0 \\
\hline 11.5 & 12.5 & Dihydro-carveol & - & - & - & 1.3 & - \\
\hline 11.9 & 12.9 & Citronellol & - & 13.6 & - & - & - \\
\hline 12.3 & 13.4 & (-)-R-Carvone & - & - & - & 69.0 & - \\
\hline 12.4 & 13.4 & Geraniol & - & 25.3 & - & - & - \\
\hline 13.1 & 13.5 & Anethol & 2.3 & - & - & - & - \\
\hline 13.7 & 13.9 & $\begin{array}{l}\text { Dihydro-carveyl } \\
\text { acetate }\end{array}$ & - & - & - & 0.9 & - \\
\hline 14.1 & 14.1 & Citronellyl acetate & - & 2.3 & - & - & - \\
\hline 14.5 & 14.2 & Geranyl acetate & - & 2.6 & - & - & - \\
\hline 14.9 & 14.7 & $\beta$-Elemene & - & 2.9 & - & - & - \\
\hline 12.9 & 14.9 & Cinnamaldehyde & 74.0 & - & - & - & - \\
\hline 15.4 & 14.9 & $\beta$-Caryophyllene & - & - & 8.6 & - & 2.5 \\
\hline 16.0 & 15.5 & $\alpha$-Humulene & - & - & 2.2 & - & - \\
\hline 13.2 & 15.6 & Thymol & - & - & - & - & 46.3 \\
\hline 14.3 & 15.8 & Eugenol & 2.7 & - & 88.6 & - & - \\
\hline 16.4 & 15.8 & $\beta$-Cubebene & - & 0.9 & - & - & - \\
\hline 13.3 & 15.9 & Carvacrol & - & - & - & - & 3.2 \\
\hline 17.0 & 16.0 & $\beta$-Cadinene & - & 1.0 & - & - & - \\
\hline 17.4 & 16.4 & Elemol & - & 2.4 & - & - & - \\
\hline 15.8 & 16.9 & Cinnamyl acetate & 5.3 & - & - & - & - \\
\hline 19.1 & 18.3 & Eudesmol & - & 2.3 & - & - & - \\
\hline 18.0 & 18.9 & $\begin{array}{l}\beta \text {-Caryophyllene } \\
\text { oxyde }\end{array}$ & - & - & 0.5 & - & - \\
\hline \multicolumn{3}{|l|}{ Total } & 93.3 & 93.9 & 99.9 & 94.6 & 96.3 \\
\hline
\end{tabular}


Table 2

Minimal inhibitory concentrations $(\mathrm{mg} / \mathrm{ml})$ of the investigated essential oils

\begin{tabular}{|l|c|c|c|c|c|c|c|}
\hline Essential oil & $\begin{array}{c}\text { Candida } \\
\text { albicans }\end{array}$ & $\begin{array}{c}\text { C.para- } \\
\text { psilosis }\end{array}$ & $\begin{array}{c}\text { Aspergillus } \\
\text { fumigatus }\end{array}$ & $\begin{array}{c}\text { Aspergillus } \\
\text { terreus }\end{array}$ & $\begin{array}{c}\text { Fusarium } \\
\text { solani }\end{array}$ & $\begin{array}{c}\text { Lichtheimia } \\
\text { corymbifera }\end{array}$ & $\begin{array}{c}\text { Rhisopus } \\
\text { microsporus }\end{array}$ \\
\hline Cinnamon & 0.19 & 0.78 & 0.19 & 0.19 & 0.19 & 3.13 & $>25$ \\
\hline Citronella & 0.39 & 0.78 & 0.78 & - & 1.56 & $>25$ & $>25$ \\
\hline Clove & 0.78 & 0.39 & 1.56 & 3.13 & 3.13 & 3.13 & 6.25 \\
\hline Spearmint & $>25$ & 6.25 & - & - & - & - & 1.56 \\
\hline Thyme & 0.78 & 0.19 & 0.39 & 0.78 & 0.78 & 0.19 & 0.19 \\
\hline
\end{tabular}

- not detected, because of no inhibition zone was achieved during screening.

MIC values of the individual EOs were lower in combination than alone, while in case of indifference the EOs kept their MIC values also in combination. The type of interaction apparently depended not only on the type of EOs combined but also on the microbes against which they were used. Saprophytic moulds with a broad spectrum of degradation enzyme activity $[32,33]$ seemed to be less susceptible. Best results (additive effect in all cases) were achieved by the combination of cinnamon and clove, both having phenolic compounds as main components. The other EO combination (cinnamon, thyme) with phenolic components resulted in indifferent and additive effect based on the fungus investigated.

Table 3

Type of interaction between essential oil combinations basing on the evaluation of the fractional inhibitory concentration index (FICI)

\begin{tabular}{|l|c|c|c|c|c|c|c|}
\hline $\begin{array}{l}\text { Essential oil } \\
\text { pairs }\end{array}$ & $\begin{array}{c}\text { Candida } \\
\text { albicans }\end{array}$ & $\begin{array}{c}\text { C. para- } \\
\text { psilosis }\end{array}$ & $\begin{array}{c}\text { Aspergillus } \\
\text { fumigatus }\end{array}$ & $\begin{array}{c}\text { Aspergillus } \\
\text { terreus }\end{array}$ & $\begin{array}{c}\text { Fusarium } \\
\text { solani }\end{array}$ & $\begin{array}{c}\text { Lichtheimia } \\
\text { corymbifera }\end{array}$ & $\begin{array}{c}\text { Rhisopus } \\
\text { microsporus }\end{array}$ \\
\hline $\begin{array}{l}\text { Cinnamon/ } \\
\text { citronella }\end{array}$ & $0.5(\mathrm{~A})$ & - & $1.0(\mathrm{I})$ & - & $2.0(\mathrm{I})$ & - & - \\
\hline $\begin{array}{l}\text { Cinnamon/ } \\
\text { clove }\end{array}$ & - & - & - & $0.75(\mathrm{~A})$ & - & $0.75(\mathrm{~A})$ & - \\
\hline $\begin{array}{l}\text { Cinnamon/ } \\
\text { thyme }\end{array}$ & - & - & $2.0(\mathrm{I})$ & - & - & $0.5(\mathrm{~A})$ & - \\
\hline $\begin{array}{l}\text { Citronella/ } \\
\text { clove }\end{array}$ & $0.5(\mathrm{~A})$ & $0.5(\mathrm{~A})$ & - & - & $2.0(\mathrm{I})$ & - & - \\
\hline $\begin{array}{l}\text { Citronella/ } \\
\text { Thyme }\end{array}$ & $0.5(\mathrm{~A})$ & $0.5(\mathrm{~A})$ & - & - & $2.0(\mathrm{I})$ & - & - \\
\hline $\begin{array}{l}\text { Thyme/ } \\
\text { Spearmint }\end{array}$ & - & - & - & - & - & - & $0.5(\mathrm{~A})$ \\
\hline
\end{tabular}

A - Addition; I - indifference; - not detected. 


\section{DISCUSSION}

EOs can have more than 50 active ingredients grouped into terpenes or aromatic compounds [4]. The antimicrobial activity of EOs is the result of several mechanisms. The main target of the EOs in pro- and eukaryotes is the cell membrane or the cell wall $[4,5,9,19]$. The membrane loses its integrity while its permeability and fluidity are increased [11, 19]. In yeasts, the content of ergosterol, a major sterol in the membrane responsible for cell integrity, was reduced by the action thyme EO [25]. Thyme and thymol reduced the virulence of Trichophyton and Aspergillus spp. with $80 \%$ reduction of elastase activity in the investigated moulds [16]. EOs thus affect microbes in several different ways. It seems that the chemical type of EO ingredients plays a considerable role in the antimicrobial activity. Best results were achieved by EOs or EO compounds containing aromatic rings $[10,12,15]$ and oxygenated terpenes [22]. Our MIC results also were lower for cinnamon, clove and thyme EOs containing aromatic compounds. Synergism has been reported for combinations of EOs or EO ingredients against E. coli [24, 27], Staphylococcus aureus [27], Listeria monocytogenes, Bacillus cereus, and Yersinia enterocolitica [10]. Fortification of cinnamon EO with cinnamaldehyde and thyme EO with thymol showed synergistic effect against $A$. flavus, and additive effect against Candida albicans and Penicillium islandicum [21]. In our experiments only "borderline synergism" (FICI values of 0.5 at the border of synergistic and additive effect) was found. Several samples are found in the literature for the synergistic activity of EOs and antifungal agents, also in case of resistant fungi $[16,28,30]$. We will also broaden our combination experiments to this field, because literature data and our results presented here both suggest that EOs in the right concentration can give an alternative or complementary therapy in the treatment of fungal infections.

\section{ACKNOWLEDGEMENTS}

This work was supported by OTKA (Hungarian Scientific Research Fund) grant No. PD 104660.

\section{REFERENCES}

1. Ahmad, A., Khan, A., Khan, L. A., Manzoor, N. (2001) In vitro synergy of eugenol and methyleugenol with fluconazole against clinical Candida isolates. J. Med. Microbiol. 59, 1178-1184.

2. Alastruey-Izquierdo, A., Hoffmann, K., de Hoog, D. S., Rodriguez-Tudela, J. L., Voigt, K., Bibashi, E., Walther, G. (2010) Species recognition and clinical relevance of the Zygomycetous genus Lichtheimia (syn. Absidia Pro Parte, Mycocladus). J. Clin. Microbiol. 48, 2154-2170.

3. Baddley, J. W., Pappas, P. G., Smith, A. C., Moser, S. A. (2003) Epidemiology of Aspergillus terreus at a University Hospital. J. Clin. Microbiol. 41, 5525-5529.

4. Bakkali, F., Averbeck, S., Averbeck, D., Idaomar, M. (2008) Biological effects of essential oils A review. Food Chem. Toxicol. 46, 446-475.

5. Bennis, S., Chami, F., Chami, N., Bouchikhi, T., Remmal, A. (2014) Surface alteration of Saccharomyces cerevisiae induced by thymol and eugenol. Lett. Appl. Microbiol. 38, 454-458. 
6. Burt, S. (2004) Essential oils: their antibacterial properties and potential application in foods - a review. Int. J. Food Microbiol. 94, 223-253.

7. Calderone, R. A. (2002) Candida and Candidiasis, ASM Press, Washington, DC, USA.

8. Cheng, V. C. C., Chan, J. F. W., Ngan, A. H. I., To, K. K. W., Leung, S. Y., Tsoi, H. W., Yam, W. C., Tai, J. W. M., Wong, S. S. Y., Tse, H., Li, I. W. S., Lau, S. K. P., Woo, P. C. Y., Leung, A. Y. H., Lie, A. K. W., Liang, L. H. S., Que, T. L., Ho, P. L., Yuen, K. Y. (2009) Outbreak of intestinal infection due to Rhizopus microsporus. J. Clin. Microbiol. 47, 2834-2843.

9. Cristani, M., D’Arrigo, M., Mandalari, G., Castelli, F., Sarpietro, M. G., Micieli, D., Venuti, V., Bisignano, G., Saija, A., Trombetta, D. (2007) Interaction of four monoterpenes contained in essential oils with model membranes: Implications for their antimicrobial activity. J. Agr. Food Chem. 55, 6300-6308.

10. Goñi, P., López, P., Sánchez, C., Gómez-Lus, R., Becerril, R., Nerín, C. (2009) Antimicrobial activity in the vapour phase of a combination of cinnamon and clove essential oils. Food Chem. 116, 982-989.

11. Hammer, K. A., Carson, C. F., Riley, T.V. (2004) Antifungal effects of Melaleuca alternifolia (tea tree) oil and its components on Candida albicans, Candida glabrata and Saccharomyces cerevisiae. J. Antimicrob. Chemother. 53, 1081-1085.

12. Iten, F., Saller, R., Abel, G., Reichling, J. (2009) Additive antimicrobial effects of the active components of the essential oil of Thymus vulgaris - chemotype carvacrol. Planta Med. 75, 1231-1236.

13. Jenei Török, J., Horváth, Gy., Vidács, A., Véha, A., Krisch, J. (2014) Antifungal activities of selected essential oils. Proceedings of the II. International Congress Food Technology, Quality and Safety, Novi Sad, Serbia. pp. 550-553. ISBN-978-86-7664-043-8.

14. Jett, B. D., Hatter, K. L., Huycke, M. M., Gilmore, M. S. (1997) Simplified agar plate method for quantifying viable bacteria. BioTechniques 23, 648-650.

15. Kamble, V. A., Patil, S. D. (2008) Spice-derived essential oils: effective antifungal and possible therapeutic agents. J. Herbs, Spices Med. Plants. 14, 129-143.

16. Khan, M. S. A., Ahmad, I., Cameotra, S. S. (2014) Carum copticum and Thymus vulgaris oils inhibit virulence in Trichophyton rubrum and Aspergillus spp. Braz. J. Microbiol. 45, 523-531.

17. Kumar, A., Shukla, R., Singh, P., Prasad, C. S., Dubey, N. K. (2008) Assessment of Thymus vulgaris L. essential oil as a safe botanical preservative against post harvest fungal infestation of food commodities. Innov. Food Sci. Emerg. 9, 575-580.

18. Lambert, R. J. W., Lambert, R. (2007) A model for the efficacy of combined inhibitors. J. Appl. Microbiol. 95, 734-743.

19. Lambert, R. J. W., Skandamis, P. N., Coote, P. J., Nychas, G.-J. E. (2001) A study of the minimum inhibitory concentration and mode of action of oregano essential oil, thymol and carvacrol. J. Appl. Microbiol. 91, 453-462.

20. Latgé, J. P. (1999) Aspergillus fumigatus and Aspergillosis. Clin. Microbiol. Rev. 12, 310-350.

21. López, P., Sánchez, C., Batlle, R., Nerín, C. (2007) Vapor-phase activities of cinnamon, thyme, and oregano essential oils and key constituents against foodborne microorganisms. J. Agric. Food Chem. $55,4348-4356$.

22. Nguefack, J., Tamgue, O., Lekagne Dongmo, J. B., Dakole, C. D., Leth, V., Vismer, H. F., Amvam Zollo, P. H., Nkengfack, A. E. (2012) Synergistic action between fractions of essential oils from Cymbopogon citratus, Ocimum gratissimum and Thymus vulgaris against Penicillium expansum. Food Control 23, 377-383.

23. Pawar, V. C., Thaker, V. S. (2006) In vitro efficacy of 75 essential oils against Aspergillus niger. Mycoses, 49, 316-323.

24. Pei, R.-S., Zhou, F., J. I., B.-P., Xu, J. (2009) Evaluation of combined antibacterial effects of eugenol, cinnamaldehyde, thymol, and carvacrol against E. coli with an improved method. J. Food Sci. 74, 379-383.

25. Pinto, E., Pina-Vaz, C., Salgueiro, L., Goncalves, M.-J., Costa-de-Oliveira, S., Cavaleiro, C., Palmeira, A., Rodrigues, A., Martinez-de-Oliveira, H. (2006) Antifungal activity of the essential oil of Thymus pulegioides on Candida, Aspergillus and dermatophyte species. J. Med. Microbiol. 55, $1367-1373$ 
26. Ramage, G., Rajendran, R., Sherry, L., Williams, C. (2012) Fungal biofilm resistance. Int. J. Microbiol. Vol. 2012, Article ID 528521, 14 pages, doi:10.1155/2012/52852

27. Sadiki, M., Balouiri, M., Barkai, H., Maataoui, H., Koraichi, S. I., Elabed, S. (2014) Synergistic antibacterial effect of Myrtus communis and Thymus vulgaris essential oils fractional inhibitory concentration index. Int. J. Pharm. Pharm. Sci. 6, 121-124.

28. Shin, S., Lim, S. (2004) Antifungal effects of herbal essential oils alone and in combination with ketoconazole against Trichophyton spp. J. Appl. Microbiol. 97, 1289-1296.

29. Steinbach, W. J., Benjamin, D. K., Kontoyiannis, D. P., Perfect, J. R., Lutsar, I., Marr, K. A., Lionakis, M. S., Torres, H. A., Jafri, H., Walsh, T. J. (2004) Infections due to Aspergillus terreus: A multicenter retrospective analysis of 83 cases. Clin. Infect. Dis. 39, 192-198.

30. Stringaro, A., Vavala, E., Colone, M., Pepi, F., Mignogna, G., Garzoli, S., Cecchetti, S., Ragno, R., Angiolella, L. (2014) Effects of Mentha suaveolens essential oil alone or in combination with other drugs in Candida albicans. Evid-Based Compl. Alt. Article ID 125904, 9 pages, http://dx.doi. org/10.1155/2014/125904

31. Tsyrkunou, A. V., Ellison, R. T., Akalin, A., Wiederhold, N., Sutton, D. A., Lindner, J., Fan, H., Levitz, S. M., Zivna, I. (2014) Multifocal Rhizopus microsporus lung infection following brush clearing. Med. Mycol. Case Rep. 6, 14-17.

32. Tzortzakis, N. G., Costas, D. (2007) Antifungal activity of lemongrass (Cymbopogon citratus L.) essential oil against key postharvest pathogens. Innov. Food Sci. Emerg 8, 253-258.

33. Zhang, N., O’Donnell, K., Sutton, D. A., Nalim, F. A., Summerbell, R. C., Padhye, A. A., Geiser, D. M. (2006) Members of the Fusarium solani species complex that cause infections in both humans and plants are common in the Environment. J. Clin. Microbiol. 44, 2186-2190. 